\title{
EDITORIAL: Conscience and Proper Medical Treatment
}

A controversy that cuts across medical practice and law is the question of the proper reach and role of conscience in medical practice. This is a particularly acute issue in the context of a publicly funded health care system where comprehensive access to treatment is supposed to be guaranteed. This special issue brings together papers that were developed from two conferences which looked at this overarching issue. The first, held in Manchester and funded by a grant from the Wellcome Trust, explored how certain treatments, procedures, and practices come to be viewed as 'proper medical treatment'. ${ }^{1}$ The second, held in Birmingham and funded by the AHRC as part of a seminar series on faith and religion in health care, ${ }^{2}$ examined the role of conscience in medical care. We are grateful to both funders for their support, and to participants at these seminars for their valuable discussions and insights. The papers in this issue critically assess the role of conscience in clinical practice and explore how we understand notions of proper medical treatment. Ethically contentious medical interventions such as abortion, withdrawing life-sustaining treatment, and assisted dying continue to spark debates about the role of the law in legitimising and/or regulating such practices. Indeed, important contributions to these debates have featured in this journal. ${ }^{3}$ The papers in this special issue seek to develop these debates by linking the concept of proper medical treatment and ideas about the

\footnotetext{
${ }^{1}$ WT102130MA, 'Transforming wrong(s) into right(s): The power of "proper medical treatment”, PI Sara Fovargue (Lancaster University), CI Alexandra Mullock (University of Manchester). Seminar held at Chancellors Conference Centre, University of Manchester, 12 September 2013.

${ }^{2}$ AHRC Grant Number: Grant Ref: AH/1026448/1: 'The influence of faith and belief on the formulation, content and operation of health law in the United Kingdom'. PI Jo Samanta (De Montfort University).

${ }^{3}$ See, e.g., M Neal, 'The Scope of the Conscience-based Exemption in section 4(1) of the Abortion Act 1967: Doogan and Wood v NHS Greater Glasgow Health Board [2013] CSIH 36' (2014) 22 Medical Law Review 409; M Campbell, 'Conscientious Objection and the Council of Europe: The right to conscientious objection in lawful medical care, Resolution 1763 (2010) Resolution adopted by the Council of Europe's Parliamentary Assembly' (2011) 19 Medical Law Review 467.
} 
medical conscience, as we see these as fundamental to medicine. These matters are particularly significant to treatments which invite polarised views and moral confusion. The question of whether such treatments are legitimate (proper medical treatment) and whether doctors and other health professionals are willing to provide them (conscience), are central to establishing the legal and ethical parameters of medical practice. The papers in this issue highlights the way in which we come to understand the boundaries of acceptability for non-clinical concerns to bear on health professionals’ decision-making.

In their paper, Sheelagh McGuinness and Michael Thomson examine the interplay between the medical profession and abortion law reform. A key focus is how abortion came under medical control and how therapeutic abortions came to constitute good medical practice. They consider the politics of the development of abortion services, including the motivations of those with a conscientious commitment to providing abortion care. They also examine the differing views within the medical profession about the legitimacy of abortion care, and highlight distinct motivations within different medical specialisms. McGuinness and Thomson conclude with observations on how lack of preparedness post enactment of the Abortion Act 1967 contributed to the current models of abortion care.

Picking up on the political nature of conscientious objection in professional roles, Jonathan Montgomery considers the particular role that statutory protections played in the political settlement that led to the Abortion Act. Although he focuses on section 4 of the Act, Montgomery's argument speaks to broader concerns about the legitimacy of professionals in a socialised health service refusing to provide certain sorts of care. 
He emphasises the pivotal role that conscience plays within medical practice and, in particular, within medical discretion. Montgomery is sceptical of the ongoing need for specific statutory protections of conscientious objection, and draws on the recent case of Greater Glasgow Health Board v Doogan to suggest that issues of conscience would be better dealt with using employment law mechanisms rather than specific statutory protections. ${ }^{4}$

Moving the focus from abortion, in their paper Sara Fovargue and Mary Neal provide a mechanism for assessing the legitimacy of conscience based exemptions to medical practices. Their arguments are generally applicable, and the starting point of their analysis is the liminal status of certain medical procedures. In keeping with a theme throughout all of the first three articles, they highlight the contested status of abortion as a form of proper medical treatment. Fovargue and Neal then move on to review various arguments for how we might assess that a particular belief is conscientiously held. They emphasise the strength of conscientious conviction and the potential for negative personal consequences of being forced to act against these beliefs. Fovargue and Neal conclude with a consideration of the limits of conscientious refusal of care, and the duties that objecting clinicians must meet.

In continuing this broadening of the analysis, Stephen Smith considers conscientious objection in non-abortion type cases, and draws on the case of Aintree $v$ James to consider how we might assess conscience claims that are not subject to predictable and generalisable rules. ${ }^{5}$ He problematizes the approach that the courts have taken towards these claims to date by specifically framing them as falling within a 'best

\footnotetext{
${ }^{4}[2014]$ UKSC 68.

${ }^{5}$ [2013] UKSC 67.
} 
interests' assessment. Smith argues that a more fruitful way of understanding these refusals of care is as a form of conscientious practice. It is a refusal to provide that treatment to that patient at that time, when a health professional might previously have provided that treatment to that patient but at a different moment in time. He develops this alternative conceptual model for decision making in James-type cases. Smith's paper thus builds on themes of earlier papers which emphasise the role that conscientious thinking plays in medical decision-making and medical discretion.

Richard Huxtable and Alexandra Mullock also consider conscientious objection at the end-of-life in the context of assisted dying. Their examination links to McGuinness and Thomson's consideration of the medical profession's impact on the development of abortion law. Huxtable and Mullock consider the likely necessity of conscientious protections if a law on assisted dying were to be enacted. As with the other contributors to this special issue, they are cognisant of the importance of conscientious belief to those who hold them and the negative impacts that acting against these beliefs can have. However, they argue that any claims of conscientious objection are duly circumscribed by the professional role, and that any legal accommodations should be clear about this. Huxtable and Mullock provide a framework for medical professional engagement with law reform with regards to assisted dying.

In the final article, José Miola adopts a broader perspective on conscience in medical practice, and considers the implications for conscience when health professionals do bad things and fail to live up to the assumption of beneficence traditionally bestowed on the profession by the law. He discusses some of the recent health scandals and 
how the 'regulation' of medical decision-making has evolved, from the era of judicial deference to the profession, to the law's more recent willingness to intervene in medical decision-making. In so doing, he assesses the space remaining for a doctor to exercise her conscience. While accepting that a more interventionist approach, which limits the doctor's freedom of conscience, may be justifiable in the light of these scandals, Miola cautions that if the space for health professionals to exercise their conscience is to be limited, something else will fill the void. If this becomes a more consumer based argument from patients then medicine may become an amoral domain, driven by patient choice. We should thus be careful what we wish for.

The papers presented in this special issue address and raise some testing questions regarding both proper medical treatment and matters of conscience. At the extremes, it could be argued that conscience-rights should pervade medical practice, alternatively that there is no proper role for health professionals, as public servants, to allow conscientious motivations to impact on their practice. ${ }^{6}$ The papers collected here suggest that neither extreme position can straightforwardly hold. An examination of proper medical practice and the role of law in protecting doctors' and patients' respective rights and responsibilities, is incomplete without a full and clear understanding of how conscience rights can and should manifest themselves in the operation of medical law. Such work is not exhausted by reference to statutory conscience clauses. Doctors and patients alike require a better understanding of the moral, and ultimately legal, basis and limits of conscientious objection in medicine.

\footnotetext{
${ }^{6}$ See, e.g., J Savulescu, ‘Conscientious objection in medicine’ (2006) 332 British Medical Journal 294; I Kennedy, 'What is a medical decision?' in Treat Me Right: Essays in Medical Law (Clarendon Press: Oxford, 1988).
} 
We hope that this special issue contributes to and moves these vitally important debates forward.

Sara Fovargue, Sheelagh McGuinness, Alexandra Mullock, Stephen Smith 